\title{
Effect of heat stress on blood parameters in indigenous sheep
}

\author{
M. S. Rana ${ }^{1^{*}}$, M. A. Hashem ${ }^{2}$, M. N. Sakib ${ }^{2}$ and A. Kumar ${ }^{2}$ \\ ${ }^{1}$ Poultry Production Research Division, Bangladesh Livestock Research Institute, Savar, Dhaka-1341 and \\ ${ }^{2}$ Department of Animal Science, Bangladesh Agricultural University, Mymensingh-2202, Bangladesh, *E-mail- \\ sohelrana.bau@gmail.com
}

\begin{abstract}
The research was conducted to study the effect of heat stress on blood parameters in indigenous sheep. Nine sheep were divided into three groups which were almost similar in age, sex and weight. Three groups were divided as zero hour $\left(T_{0}\right)$, four hours $\left(T_{4}\right)$ and eight hours $\left(T_{8}\right)$ heat exposure to direct sunlight. During experimental period temperature-humidity index (THI) value was calculated as 27.09 which indicate $T_{4}$ and $T_{8}$ groups were subjected to heat stress condition for at least four hours and eight hours respectively every day. The amount of red blood cell (RBC), hemoglobin ( $\mathrm{Hb} \%$ ) and packed cell volume $(P C V \%)$ were increased significantly $(p<0.05)$ with the increase of heat stress but the amount of white blood cell $(\mathrm{WBC})$ had no significant difference $(P>0.05)$ among the treatment groups. It can be concluded that heat stress had significant changes on some blood parameters in indigenous sheep.
\end{abstract}

Keywords: Heat stress, Sheep, Red blood cell, Hemoglobin, White blood cell, Packed cell volume

\section{Introduction}

Sheep are important in Bangladesh, providing meat and wool. During the last twelve years sheep population increased 2.5 times, with annual growth rate of $5 \%$ (BBS, 2008). There are 2.7 million sheep (BBS, 2008), of which $32 \%$ are reared in three ecological zones, viz,. Barind, Jamuna basin and Coastal areas. Most of the sheep are indigenous, with few crossbreds (Bhuiyan et al., 2006) and are capable of bi-annual lambing and multiple births. Native sheep (Ovis aries) might have originated from the wild Urial (Ovis orientalis vignei) of Asia. The changes in the biological functions of sheep due to exposure to heat stress include the depression in feed intake and utilization, disturbance in the metabolism of water, protein, energy and mineral balances, enzymatic reactions, hormonal secretions and blood metabolites (Habeeb et al., 1992; Marai et al., 2000). The thermal environment is a major factor that negatively affects sheep performance. Increased body temperature and respiration rate are the most important signs for heat stress in sheep. The increase in body temperature is associated with marked reduction in feed intake, redistribution in blood flow and changes in endocrine functions that will affect negatively the productive and reproductive performance of the sheep (Abouheif \& Alsobayel, 1982, 1983: Eltawill \& Narendran, 1990). These physiological adjustments are essential to maintain normal body temperature and to prevent hyperthermia (Bhattacharya \& Uwayjan 1975; Al-Haidary, 2000; Lowe et al., 2001). Moreover, under these conditions the animal's productivity severely affected that result in a tremendous economic loss for the sheep industry.

A major strategy to reduce the effect of heat stress on animals is to alter the environment through the use of sheds, fans or evaporative cooling (Bucklin et al., 1991). Such practices are not possible in semiintensive systems as goats are grazed in the open during most of the day. Moreover, Bangladesh is a sub tropical country and sheep are generally reared by scavenging of naturally grown grasses. So they have to face heat stress during summer months. But there is no information available on the effect of chronic heat stress on behavior, physiological, biochemical and productive indices in sheep in Bangladesh. However, reports on the effects of chronic heat stress on physiological indices in indigenous sheep are scarce and sporadic. Therefore, there is urgent demand to address the effect of heat stress on physiological and biochemical traits in sheep. Therefore, the present research work was undertaken to determine the effect of heat stress on blood parameters in indigenous sheep. 


\section{Materials and Methods}

\section{Experimental site}

Field trial was carried out in Goat, sheep and horse farm under the department of Animal Science. Laboratory analyses of the experimental samples were carried out in the laboratory of same department and also in the department of Physiology, Bangladesh Agricultural University, Mymensingh.

\section{Selection of the experimental sheep}

Nine indigenous sheep which were almost similar in age, sex and weight were selected for the experiment. Means of estimating the severity of heat stress was proposed using both ambient temperature and relative humidity, termed as the temperature humidity index (THI) (LPHSI, 1990; Marai et al. (2007). When temperature is measured $\left({ }^{0} \mathrm{~F}\right)$, the equation to determine THI is as follows (LPHSI, 1990): $\mathrm{THI}=\mathrm{db}{ }^{0} \mathrm{~F}-\left\{(0.55-0.55 \mathrm{RH})\left(\mathrm{db}{ }^{0} \mathrm{~F}-58\right)\right\}$ where $\mathrm{db}{ }^{0} \mathrm{~F}$ is the dry bulb temperature in ${ }^{0} \mathrm{~F}$ and $\mathrm{RH}$ is the relative humidity $(\mathrm{RH} \%) / 100$, for sheep and goats. The obtained values indicate the following: values $<82=$ absence of heat stress; 82 to $<84=$ moderate heat stress; 84 to $<86=$ severe heat stress and over $86=$ extreme severe heat stress (LPHSI 1990). When the temperature is expressed in ${ }^{0} \mathrm{C}$, the equation of Marai et al. (2001) changes as follows: THI $=\mathrm{db}{ }^{0} \mathrm{C}-\left\{(0.31-0.31 \mathrm{RH})\left(\mathrm{db}{ }^{0} \mathrm{C}-14.4\right)\right\}$ where $\mathrm{db}{ }^{0} \mathrm{C}$ is the dry bulb temperature $\left({ }^{\circ} \mathrm{C}\right)$ and $\mathrm{RH}$ is the relative humidity $(\mathrm{RH} \%) / 100$. The values obtained indicate the following: $<22.2=$ absence of heat stress; 22.2 to $<23.3=$ moderate heat stress: 23.3 to $<25.6$ = severe heat stress and 25.6 and more = extreme severe heat stress (Marai et al., 2001).

\section{Management of sheep}

Animals were housed in semi-intensive housing system in the Goat, sheep and horse farm of the department of Animal Science. All the sheep were kept in three groups (one group consists of three animals) in the room separated with fence. One group was assigned as control (average room temperature $23.6^{\circ} \mathrm{C}$ and relative humidity $65 \%$ i.e. zero hour heat exposure), and the rest two groups were served as heat stress such as 4 hours heat exposure from 10 am to 2 pm and 8 hours heat exposure from 9 am to $5 \mathrm{pm}$. Roughage and concentrate feeds were supplied everyday at adequate amount. A large water trough was provided for each group to supply fresh water available ad libitum. The house was well ventilated and the space per animal was adequate. Cleaning and hygienic management was maintained regularly. The floor, stall, water trough, and feeder were cleaned every day. The faeces were removed carefully from the house.

\section{Duration of the experiment}

The heat stress period was 45 days, from 20 April 2011 to 5 June 2011. Before starting the collection of experimental data, all animals were subjected for acclimatization with the environment (e.g., daily routine activities) for about two months. All the animals were given 15 days for their psychological and physiological adjustment before starting the real experiment for data collection.

\section{Measurement of ambient temperature and relative humidity}

The data about ambient temperature and relative humidity of these experimental days was collected from Meteorological Centre, Department of Irrigation and Water Management, Bangladesh Agricultural University, Mymensingh.

\section{Determination of blood parameters}

Jugular vein was selected for blood collection from all experimental animals by the method described by Schalm et al. (1975). The site of collection was made sterile by using ethyl alcohol to prevent the risk of phlebitis. Immediately after collection into syringe, blood was transferred to sterile test tube containing anticoagulant (4\% Sodium Citrate solution) at a ratio of 1:10. Because of time constraint, this blood was then carried out to Physiology Laboratory in an ice carrier and preserved under refrigeration temperature. The sample was then examined for various hematological parameters on the following day. Hemoglobin (Hb) was estimated first after collection of blood. This test was done by Acid-Hematin method. Total erythrocyte count (RBC), total leukocyte count (WBC) and packed cell volume (PCV) were determined as per technique described by Shastry (1983). Body weight, length and heart girth of the animals were also taken. 


\section{Statistical analysis}

The data in this experiment were analyzed statistically using the analysis of variance technique in a computer using SAS statistical computer package programme (1998) in accordance with the principle of Completely Randomized Design (CRD). Duncan's Multiple Range Test was done to compare variations between treatments.

\section{Results and Discussion}

In the present study during experimental period average temperature was $27.84^{\circ} \mathrm{C}$ and average relative humidity was $81.90 \%$. Hence, $\mathrm{THI}$ value was 27.09 which indicate $\mathrm{T}_{4}$ and $\mathrm{T}_{8}$ groups were subjected to extreme severe heat stress condition for at least four hours and eight hours respectively every day.

\section{Effect of heat stress on body parameters in sheep}

Table 1 shows initial weight, slaughter weight, body length and heart girth in non-exposure, 4 hours and 8 hours of heat exposure to the sheep.

Table 1. Effect of heat stress on body parameters in sheep

\begin{tabular}{|l|c|c|c|c|}
\hline Parameters & $\mathrm{T}_{0}$ & $\mathrm{~T}_{4}$ & $\mathrm{~T}_{8}$ & $\begin{array}{c}\text { Level of } \\
\text { significance }\end{array}$ \\
\hline Initial body weight $(\mathrm{kg})$ & $12.3 \pm 0.60$ & $12.33 \pm 0.33$ & $12.66 \pm 0.88$ & $\mathrm{NS}$ \\
\hline Final body weight $(\mathrm{kg})$ & $12.5 \pm 0.57$ & $12.83 \pm 0.33$ & $13.0 \pm 0.57$ & $\mathrm{NS}$ \\
\hline Body length $(\mathrm{cm})$ & $45 \pm 1.45$ & $46.00 \pm 2.30$ & $43.33 \pm 1.45$ & $\mathrm{NS}$ \\
\hline Heart girth $(\mathrm{cm})$ & $45 \pm 1.45$ & $58.33 \pm 2.91$ & $53.33 \pm 1.20$ & $\mathrm{NS}$ \\
\hline
\end{tabular}

Means with different superscript in the same row differ significantly; NS, $p>0.05$, non significant, $\mathbf{T}_{\mathbf{0}}=$ zero hour heat exposure group; $\mathbf{T}_{4}=$ four hour heat exposure group; $\mathbf{T}_{8}=$ eight hour heat exposure group

Initial and final body weight was $12.3 \pm 0.60$ and $12.5 \pm 0.57,12.33 \pm 0.33$ and $12.83 \pm 0.33$, and $12.66 \pm 0.88$ and $13.0 \pm 0.57 \mathrm{~kg}$ for $T_{0}, T_{4}$ and $T_{8}$, respectively. Likewise, the body length and heart girth was $45 \pm 1.45$ and $45 \pm 1.45,46.00 \pm 2.30$ and $58.33 \pm 2.91$, and $43.33 \pm 1.45$ and $53.33 \pm 1.20 \mathrm{~cm}$ for $\mathrm{T}_{0}, \mathrm{~T}_{4}$ and $\mathrm{T}_{8}$, respectively. No significant differences $(p>0.05)$ were observed for body weight, length and heart girth among the treatment groups.

\section{Effect of heat stress on blood parameters in sheep}

Table 2 shows red blood cell (RBC), Hemoglobin $(\mathrm{Hb})$, white blood cell (WBC) and packed cell volume (PCV) in non-exposure 4 hours and 8 hours of heat exposure to the sheep. There was no significant difference among the groups for effect of heat stress on WBC of the sheep. The amount of $\mathrm{RBC}, \mathrm{Hb} \%$ and PCV\% were significantly higher $(p<0.05)$ in 8 hour group which were $10.28 \pm 0.27,9.80 \pm 0.23$ and $31.67 \pm 1.45$ respectively than non-exposure group but there is no significant difference $(p>0.05)$ between non-exposure and 4 hour exposure groups and between 4 hour and 8 hour exposure groups.

Table 2. Effect of heat stress on blood parameters in sheep

\begin{tabular}{|l|c|c|c|c|}
\hline Parameters & $\mathrm{T}_{0}$ & $\mathrm{~T}_{4}$ & $\mathrm{~T}_{8}$ & $\begin{array}{c}\text { Level of } \\
\text { significance }\end{array}$ \\
\hline RBC (million/cubic $\mathrm{mm})$ & $8.96^{\mathrm{b}} \pm 0.46$ & $9.70^{\mathrm{ab}} \pm 0.22$ & $10.28^{\mathrm{a}} \pm 0.27$ & ${ }^{\mathrm{a}}$ \\
\hline Hb (g/percent) & $8.67^{\mathrm{b}} \pm 0.24$ & $9.06^{\mathrm{ab}} \pm 0.29$ & $9.80^{\mathrm{a}} \pm 0.23$ & ${ }^{*}$ \\
\hline WBC (Thousand/cubic mm) & $8.09 \pm 0.42$ & $8.76 \pm 0.18$ & $9.03 \pm 0.63$ & $\mathrm{NS}$ \\
\hline PCV (\%) & $27.00^{\mathrm{b}} \pm 1.15$ & $28.66^{\mathrm{ab}} \pm 1.20$ & $31.67^{\mathrm{a}} \pm 1.45$ & ${ }^{*}$ \\
\hline
\end{tabular}

Means with different superscript in the same row differ significantly; ${ }^{*}, p<0.05 ; N S, p>0.05$, non significant, $\mathbf{T}_{0}=$ zero hour heat exposure group; $\mathbf{T}_{4}=$ four hour heat exposure group; $\mathbf{T}_{8}=$ eight hour heat exposure group

Al-Haidary (2004) reported that exposure to heat stress resulted in a significant $(P<0.05)$ increase in packed cell volume (PCV) which is in close agreement with the findings of this study. The higher PCV values had been reported to be an adapted mechanism to provide water necessary for evaporative cooling process. He also found higher value of RBC in heat stress group (8.4) than in control group (7.9) and Hemoglobin in heat stress group (11.4) than in control group (11.05). Sivakumar et al. (2010) 
measured that $\mathrm{PCV}$ and $\mathrm{Hb}$ were significantly decreased $(p<0.05)$ in the heat stress group. In the present study, both PCV and hemoglobin were increased in the heat stress group and this is consistent to the findings of Srikandakumar et al. (2003) in sheep and Abdel Samee et al. (1992) in goats. This increase of hemoglobin and PCV levels could be due to either increased on attack of free radicals on the RBC membrane, which is rich in lipid content, and ultimate lysis of RBC or adequate nutrient availability for hemoglobin synthesis as the animal consumes more feed or decreases voluntary intake under heat stress.

\section{Conclusion}

From the above study, it can be concluded that heat stress significantly affects on blood parameters i.e. RBC, hemoglobin and PCV levels of indigenous sheep. Further, in depth study is needed to explore more information to minimize the effect of heat stress on blood parameters for both qualitative and quantitative production approaches of sheep meat.

\section{References}

Abdel-Samee, A.M., Kamal, T.H., Abu-Sinna, G. and Hagag, A.M. 1992. Alleviation of the heat load on lactating goats with the use of diuretics and drinking cool water. Beitr. Trop. Landwirtsch. Veterinarmed., 30 (1): 91-99.

Abouheif, M.A. and Alsobayel, A.A. 1982. Reproductive performance of Saudi Arabian black Najdi ewes under the local environment in Riyadh area. World Rev. Anim. Prod., 18: 9.

Abouheif, M.A. and Alsobayel, A.A. 1983. Environmental and genetic factors influencing birth weight of black Najdi lambs. World Rev. Anim. Prod., 19: 51.

Al-Haidary, A. 2000. Effect of heat stress on some thermoregulatory responses of cattle, sheep and goat. Zag. Vet. J., 28: 101-10.

Al-Haidary, A. 2004. Physiological responses of naimey sheep to heat stress challenge under semi-arid environments. Int. J. Agri. Biol., 6 (2): 2004.

BBS (Bangladesh Bureau of Statistics), 2008. 'National Accounts Statistics' of various issues and calculated by Finance Division.

Bhattacharya, A.N. and Uwayjan, M. 1975. Effect of high ambient temperature and low humidity on nutrient utilization and some physiological responses in Awasi sheep fed different level of roughage. J. Anim. Sci., 40: 320-8.

Bhiyan, M., Ismail, E., Abdel-Latif, H., Hassan, G.A. and Salem, M.H. 2006. Water metabolism and requirements of sheep as affected by breed and season. World Rev. Anim. Prod, 30 (1-2): 95-105.

Bucklin, R.A., Turner, L.W., Beede, D.K., Bray, D.R. and Hemken, R.W. 1991. Methods to relieve heat stress for dairy cows in hot, humid climates. Appl. Eng. Agric., 7 (2): 241-246.

Eltawill, A. and Narendran, R. 1990. Ewe productivity in four breed of sheep in Saudi Arabia. World Rev. Anim. Prod., 25: 93.

Habeeb, A.A., Marai, I.F.M. and Kamal, T.H. 1992. Heat stress. In: Philips, C., Piggens, D. (Eds.), Farm Animals and the Environment. C.A.B. International, pp. 27-47.

Lowe, T.E., Christian, J., Cook, Ingram, J.R. and Phillip. 2001. Impact of climate on thermal rhythm in pastoral sheep. Physiol. Behavior, 74: 659-64.

LPHSI, 1990. Livestock and Poultry Heat Stress Indices Agriculture Engineering Technology Guide. Clemson University, Clemson, SC 29634, USA.

Marai, I.F.M., Ayyat, M.S. and Abd El-Monem, U.M. 2001. Growth performance and reproductive traits at first parity of New Zealand White female rabbits as affected by heat stress and its alleviation, under Egyptian conditions. Tropical Animal Health and Production, 33: 457-462.

Marai, I.F.M., Bahgat, L.B., Shalaby, T.H. and Abdel-Hafez, M.A. 2000. Fattening performance, some behavioural traits and physiological reactions of male lambs fed concentrates mixture alone with or without natural clay, under hot summer of Egypt. Ann. Arid Zone, 39 (4): 449-460.

Marai, I.F.M., Bahgat, L.B., Shalaby, T.H. and Abdel-Hafez, M.A. 2007. Fattening performance, some behavioural traits and physiological reactions of male lambs fed concentrates mixture alone with or without natural clay, under hot summer of Egypt. Annals of Arid Zone, 39: 449-460.

Schalm, O.W., Jam, N.C. and Corrola, E.J. 1975. Veterinary Haematology. ${ }^{\text {rd }}$ Edition, Lea and Febiger, Philadelphia, USA.

Shastry, G.A. 1983. Haematological values of cows of Assam. Veterinary clinical Pathology. GBS Publishers and distributors, Delhi.

Sivakumar, V.N., Singh, G. and Varshney, V.P. 2010. Antioxidants Supplementation on Acid Base Balance during Heat Stress in Goats. Asian-Aust. J. Anim. Sci., 23 (11): $1462-1468$.

Srikandakumar, A., Johnson, E.H. and Mahgoub, O., 2003. Effect of heat stress on respiratory rate, rectal temperature and blood chemistry in Omani and Australian Merino sheep. J. Small-Ruminant-Research. 49 (2): 193-198. 